\section{О.Р. Іванців}

Івано-Франківський національний медичний університет,

Івано-Франківськ, Україна

Надійшла: 24.08.2021

Прийнята: 06.09.2021
DOI: https://doi.org/10.26641/1997-9665.2021.3.191-195

УДК 37.018.43+614.253.4+614.46

ОСОБЛИВОСТІ ДИСТАНЦЙНОЇ ФОРМИ ВИКЛАДАННЯ ДИСЦИПЛІНИ "КЛІНІЧНА АНАТОМІЯ ТА ОПЕРАТИВНА ХІРУРГІЯ" У СТУДЕНТІВ ІВАНО-ФРАНКІВСЬКОГО НАЦІОНАЛЬНОГО МЕДИЧНОГО УНІВЕРСИТЕТУ

Ivantsiv O.R. (iD $\square$ Peculiarities of online training in the discipline of "Clinical anatomy and operative surgery" for the students of Ivano-Frankivsk national medical university.

Ivano-Frankivsk National Medical University, Ivano-Frankivsk, Ukraine.

ABSTRACT. Background. Since mid-March 2020, the entire medical community of Ukraine has faced a new problem - the lack of experience and technical support for giving online classes. Purpose: to analyze the features of online training in the discipline of "Clinical Anatomy and Operative Surgery" for the second-year students of the medical faculty in IFNMU. Results. We have identified the benefits of online training. Thus, being at home, students can acquire knowledge under the conditions of constant mastering of educational material, so their theoretical basis will be quite thorough; online training also gives an opportunity to study the material anywhere with Internet access. In quiet home conditions online training provides mastering modern information and communication technologies. However, there are also the disadvantages of online training: the inability to form a consistent view and master practical skills in the discipline on their own, due to lack of necessary instruments, phantoms, models, etc., so it is difficult to obtain thorough knowledge, sometimes because of low capacity of the electronic network. Conclusion. In online training of the medical students, we outlined the following peculiarities of giving classes: remoteness, flexibility, mass, practicality, usability, economy, parallelism and modularity.

Key words: online training, medical students, education, practical skills, Internet.

\title{
Citation:
}

Ivantsiv OR. [Peculiarities of online training in the discipline of "Clinical anatomy and operative surgery" for the students of Ivano-Frankivsk national medical university]. Morphologia. 2021;15(3):191-5. Ukrainian.

DOI: https://doi.org/10.26641/1997-9665.2021.3.191-195

Ivantsiv O.R. 0000-0002-4366-6406

$\bowtie$ olga_ivantsiv@ukr.net

(C) Dnipro State Medical University, «Morphologia»

\section{Вступ}

Пандемія Covid-19 внесла значні корективи не тільки в уже сформовані механізми життя людей (дотримання дистанції, маскового режиму, часта дезінфекція поверхонь та миття рук, самоізоляція тощо), а й у технології та форми навчання студентів. Ось уже другий рік медичні ВУЗи змушені працювати за змішаної форми навчання, яка включає використання як дистанційного, так i стаціонарного навчання. Справжнім викликом для медичних ВНЗ було організувати якісне он-лайн навчання за короткий проміжок часу після початку карантинних обмежень. У багатьох університетах, де здобувачі освіти навчаються заочно частково уже була налагоджена база навчальних матеріалів 3 проведення занять та оцінювання знань студентів ди- станційно, чого не скажеш про медичні вузи, де впровадження практичних навиків та їх оцінка у он-лайн форматі є досить проблематичною. Проте завдяки розвитку телекомунікативних інтернет-технологій, правильно організованому процесу навчання викладачів щодо користування ними це стало можливим.

Клінічна анатомія та оперативна хірургія є інтегративною дисципліною, що здатна систематизувати отримані знання з морфології людини у відповідності до практичних медичних потреб. Вона являється наче «мостом», плавним переходом від теоретичних до клінічних дисциплін. Вагомим моментом в освоєнні даної дисципліни $€$ оволодіння навичками клінічного мислення, яке починає розвиватися у студентів під час розв'язування ситуаційних задач та виконанні 
практичних навичок [1]. Проте медичний освітній простір до пандемії коронавірусної хвороби не мав досвіду навчання студенів-медиків дистанційно, саме тому найбільше постраждали якість та техніка виконання практичних навичок.

Мета роботи - проаналізувати особливості дистанційної форми викладання дисципліни "Клінічна анатомія та оперативна хірургія" у студентів II курсу медичного факультету ІФНМУ.

\section{Результати та їх обговорення}

Дистанційне навчання - одна із форм навчального процесу, яке дає змогу забезпечувати нерозривність процесу навчання за надзвичайних обставин, які унеможливлюють аудиторне відвідування занять у медичних закладах освіти. Для останніх дана форма стала новим навчальним явищем, яке забезпечило трансформацію класичних методів навчання завдяки впровадженню сучасних веб-технологій. 3 початком пандемії дана форма стала так званою освітньою системою 21 сторіччя, яка змогла реалізувати право людини на освіту та доступ до вузькопрофільної інформації [2].

Відповідно до Постанови Кабінету Міністрів № 211 «Про запобігання поширенню на території України коронавірусу Covid-19» від 11.03.2020 р., наказу Міністерства освіти і науки України від 16.03.2020 № 406 «Про організаційні заходи для запобігання поширенню коронавірусу Covid-19» усі викладачі та студенти ІФНМУ, використовуючи сайт «Хмарні сервіси Office 365», зокрема додаток Teams, змогли перейти на дистанційне навчання. Спершу адміністрацією та відділом інформаційно-аналітичного забезпечення було організоване навчання у формі вебінарів та покрокових інструкцій із користування додатками. Практичні заняття та лекції $з$ клінічної анатомії та оперативної хірургії почали проводитися у форматі онлайн-конференцій на платформі Teams. Для цього попередньо створювалися команди за типом «Клас», які відповідали академічній групі студентів. У таких командах заплановувалися наради, що відображали дату та час проведення практичного заняття за розкладом та календарно-тематичним планом, студентам на електронну пошту автоматично приходило сповіщення про наявність та початок наради. Даний додаток виявився зручним у користуванні, оскільки дав змогу студентам однієї групи комунікувати 3 викладачем, використовуючи відеозв'язок. При цьому у створеній нараді є чат для обговорень, файлообмінник, викладач мав змогу під час заняття демонструвати презентації, відеосюжети та інші наочні матеріали. Окремо були створені команди для читання лекцій, що відповідали кількості студентів в одному потоці та команди для проведення консультацій і відробок пропущених практичних занять і лекцій [3].

Кожне практичне заняття 3 дисципліни
«Клінічна анатомія та оперативна хірургія» має містити три складові: тестовий контроль, усне опитування по контрольних питаннях теми, а також практичні навики. У відповідності до календарно-тематичного плану, студенти II курсу медичного факультету за спеціальністю «Лікувальна справа» та «Педіатрія» мають 5 лекцій та 19 практичних занять, останне з яких представлене підсумковим модульним контролем (ПМК).

Для тестування студентів використовували тестові системи test.if.ua та pmk.ifnmu.edu.ua. Перша зручна для навчання в режимі «тренера» при підготовці тестових завдань, тоді як друга під час безпосереднього тестування на занятті, оскільки студенту необхідно спершу увійти у свій акаунт, увівши адресу особистої електронної пошти та пароль, при цьому надається тільки одна спроба протестуватися. Систему pmk.ifnmu.edu.ua спеціально розробили для дистанційного оцінювання знань. Вона дає викладачу можливість розпізнавати у статистиці кількість виходів студента з вікна програми під час тестування та відкриття ним інших вкладок. Це унеможливлює списування тестових завдань 3 даного гаджету, що висвітлено у Інструкції зі збору даних оцінювання студентів. Під час практичного заняття студенту необхідно правильно відповісти на 8, 9 чи 10 тестових завдань з десяти можливих (тобто набрати більше 75\% правильних відповідей), які викладач конвертує у бали: 0,5; 1 та 1,5 відповідно.

Усна частина заняття оцінюється від нуля до трьох балів. Дистанційно, вона стала можливою завдяки використанню платформи MicrosoftTeams, яку можна вважати центром для командної роботи у офісі 365 . Програма забезпечує якісну комунікацію та швидкий обмін навчальними матеріалами. Викладач он-лайн опитує тему, розкриває ключові питання, коригує хибні відповіді, пояснюючи незрозумілі поняття та терміни, використовує завантажені до офісу навчальні матеріали (відеосюжети, презентації, фотографії муляжів та навчальних таблиць тощо). Викликом для викладачів став пошук таких діалогових комунікацій, які сприяли б зацікавленості студента впродовж усього практичного заняття у дистанційній формі. На сьогодні різні навчальні платформи пропонують вебінари та курси, які дозволять підвищити рівень педагогічної майстерності та подачі матеріалу онлайн [4].

Під час практичних занять із клінічної анатомії та оперативної хірургії студенти мають змогу оволодіти такими практичними навичками, як розпізнавання хірургічних інструментів та правилами користування ними, роз'єднання та з'єднання шкіри, підшкірної клітковини та поверхневої фасції, м'язів, виконання інфільтраційної анестезії за Вишневським, обкладання 
операційного поля, підготовка голкотримача до роботи тощо. Як же виглядав розбір практичних навичок та інших частин практичного заняття в дистанційному режимі, давайте проаналізуємо. Для оволодіння студентами практичними навичками з базової хірургічної техніки під час консультацій демонструвалися відеоролики, підготовлені викладачами кафедри у відповідності до алгоритмів їх виконання. Дані відео були розміщені на сайті кафедри у папці «Відеокомплекси практичних занять», кожен студент мав змогу переглядати їх у зручний для себе час повторно. На допомогу в оволодінні практичними навичками студентам надані покрокові інструкції їх виконання. Окремі студенти придбали власні інструменти та тренажери, що імітують тканини тіла та опановували окремі навички дистанційно. Викладачами кафедри у режимі відеоконсультацій продемонстровано дані навички із зазначенням особливостей застосування хірургічних інструментів загального призначення на кожному етапі. Тематичні практичні навички, що випали за період карантину, були розглянуті зі студентами із використанням PowerPoint, iз сайту YouTube завантажено велику базу відеосюжетів по тематичних практичних навичках. На занятті останні оцінюються від 0 до 1,5 бала, при цьому спершу студенти переглядають відео із демонстрацією даного навичку, а потім разом із викладачем обговорюють ключові аспекти його виконання. Саме на цьому етапі, на етапі оволодіння практичними навичками відмічено найбільші проблеми у викладанні нашої дисципліни, адже якщо певні практичні навички терапевтичних кафедр можна освоїти в домашніх умовах, то без використання хірургічних інструментів на фантомах, муляжах, в анатомічному залі на трупному матеріалі неможливо оцінити правильність їх виконання. 3 метою освоєння студентами інструментами спеціального призначення, крім навчальної літератури рекомендовано додаток AtlasTools, де у 3-d зображенні можна ознайомитися із інструментом, побачити його точки прикладання тощо.

ПМК проводився у відповідності до кредитно-трансферної системи освіти, проте під час дистанційного навчання його проведення теж мало особливості. Для перевірки знань студентів під час підсумкового модульного контролю використовували для тестування систему pmk.ifnmu.edu.ua. Студенти згідно розкладу занять повинні були проходити он-лайн тестування 3 підсумкового модульного контролю та отримати більше 75\% правильних відповідей для зарахування результату, який конвертується у бали від 27 до 35. Слід відмітити, що студенту надається лише одна спроба он-лайн тестування. Усне опитування під час ПМК включало відповіді студента на два питання та ситуаційну задачу, при цьому вибір питань викладачі прово- дили у системі Random, яка дозволяє генерувати випадкові числа із вказаної вибірки. Контроль засвоєння практичної частини вимушено здійснений лише за допомогою розв'язування ситуаційних задач, а не традиційно $з$ демонстрацією самих навичок на препаратах, ізольованих органах чи моделях тканин.

Як показали результати попереднього аналізу дистанційного навчання, відмічено значно меншу кількість пропусків занять (відсутність результатів тестування по темах та відсутність студента у команді Teams), значно вищу успішність за результатами дистанційного тестування та непогані усні відповіді під час ПМК, однак повну відсутність можливості контролю оволодіння студентами практичними навичками. Про остаточні результати дистанційного навчання можна говорити після детального аналізу та державної атестації під час здачі державного практично-орієнтованого іспиту. В процесі проведеного навчання студентів-медиків можна окреслити наступні особливості дистанційної форми проведення занять:

а) віддаленість (полягає у тому, що учасники навчального процесу можуть перебувати на значних відстанях один від одного, що не буде значною перешкодою для отримання інформації завдяки доступу до інтернету);

б) гнучкість (здобуття освітніх послуг здійснюється у зручний час, кожен здобувач освіти може навчатися стільки, скільки йому необхідно для засвоєння нового матеріалу);

в) масовість (кількість учасників навчального процесу може збільшуватися, наприклад, під час читання лекцій, що не вплине на саму якість навчання);

г) апрактичність (відсутність можливості виконувати практичні навички студентамимедиками у домашніх умовах, оскільки вони потребують наявності хірургічного інструментарію, муляжів, трупного матеріалу);

г) економічність (відсутність витрат на проживання в іншому місці, транспортних витрат);

д) паралельність (деякі учасники навчального процесу поєднують навчання 3 професійною діяльністю чи поєднують навчання у кількох навчальних закладах);

е) модульність (усі дисципліни вивчаються згідно Болонської системи освіти; а отримані знання із різних предметів створюють уявлення про цілу галузь.

В умовах дистанційного навчання зростає роль самостійної позааудиторної роботи, а функція викладача полягає також у ефективній організації самоосвіти студентом, що дозволить сформувати особистість, здатну до саморозвитку. Проблемою самостійного опрацювання матеріалу є великий його обсяг, необхідність конспектування та формулювання коротких висновків із прочитаного матеріалу [5, 6]. 
Окремо можна також виділити переваги та недоліки дистанційної освіти. Так, у студентів зростає кількість вільного часу, який вони б витрачали на шлях до університету та переміщення між кафедрами. Під час дистанційного навчання забезпечується максимальна ізоляція студентів, що сприяє мінімізації передачі ГРЗ та коронавірусної інфекції. Спокійна домашня атмосфера дозволяє краще показати свій рівень знань під час усного опитування по контрольних питаннях теми. Дистанційне навчання здатне забезпечити індивідуальний підхід до студента, адже у будьякий зручний час студент може задати викладачу запитання у чаті та оперативно отримати відповідь, не витрачаючи час на дорогу до кафедри. Студенти мають змогу навчатися у різному темпі, який індивідуально необхідний кожному для засвоєння нового матеріалу.

Найвагомішими недоліками дистанційної освіти є технічні проблеми, пов'язані з доступом до мережі Інтернет, що у різних місцевостях може мати погану швидкість, цілком залежить від наявності електроенергії, провайдера тощо. Багато студентів використовують додаток Microsoft Teams на власному смартфоні, де візуалізація презентацій і відео буде нечіткою через погану роздільну здатність девайсу. В багатьох студентів спостерігається втрата інтересу до навчання, пов'язана із постійним перебуванням на одному робочому місці та підвищена втомлюваність. Відсутність можливості застосовувати отримані знання на практиці $є$ ще одним вагомим недоліком дистанційної форми навчання. Навіть найбільш сучасні тренажери, перегляд відеолекцій не замінять майбутнім медикам «живу» практику, тому повністю дистанційна форма навчання не може повною мірою забезпечити якісний навчальний процес студентам-медикам. Не усі студенти мають сильну мотивацію до навчання, через що під час комп'ютерного тестування використовували можливість недобросовісного проходження тестової частини заняття, де зі зниженням контролюючої функції викладача з'являється багато можливостей для спису- вання.

\section{Підсумок}

Отже, розглянувши основні переваги та недоліки дистанційного навчання при вивченні дисципліни «Клінічна анатомія та оперативна хірургія» нами було виокремлено наступні фактори: слідкування за думками викладача, більша концентрація уваги студентів спостерігається за участю візуального контакту; дистанційна форма не забезпечує практичної зорієнтованості набутих знань, вона $є$ звісно потужною телекомунікативною технологією, проте потребує значних зусиль від студентів у опануванні дисципліни, доброчесності, збільшується обсяг навантаження на викладача в оцінці знань студентів. Проте найбільшою перевагою дистанційної освіти $\epsilon$ можливість доступу студентів до навчальних ресурсів, використовуючи мінімальні фінансові навантаження. Використання додатку Tеams дозволило організувати спільну активну співпрацю між викладачами кафедри та студентами, які вивчають клінічну анатомію та оперативну хірургію. Заняття у он-лайн форматі дозволило викладачам не лише пояснювати важливу інформацію, а й оцінювати рівень знань студентів. Брак роботи із хірургічним інструментарієм та в анатомічному залі викладачі старалися компенсувати відеоматеріалами. Тому, під час даної форми навчання неможливо забезпечити повноцінну практичну підготовку студентів медиків. Підсумовуючи вищенаведене, під час карантину можливе запровадження дистанційного навчання, однак з подальшим відпрацюванням студентами практичних навичок, правильністю їх виконання та контролю.

Перспективи подальших розробок

В подальшому плануємо порівняти результати складання підсумкового модульного контролю 3 дисципліни до пандемії Covid-19 та в умовах дистанційного навчання.

Інформація про конфлікт інтересів

Потенційних або явних конфліктів інтересів, пов'язаних 3 цим рукописом, на момент публікації не існує і не передбачається.

\section{Літературні джерела References}

1. Vovk YN. [Clinical anatomy - the basis of modern morphology and surgery]. Morphologia. 2016;10(3):354-357. Ukrainian. https://doi.org/10.26641/1997-9665.2016.3.354-357

2. Kushch OG, Omelyanchik VM, Bessarab GI. [Distance learning in the system of medical education]. Medical education. 2017;4:85-89. Ukrainian. https://doi.org/10.11603/me.24145998.2017.4.8283

3. Lisetska IS. [Distance form of learning medical students as a challenge of today]. Modern
Pediatrics. 2020;7(111):81-86. Ukrainian. https://doi.org/10.15574/SP.2020.111.81

4. Ministry of Education and Science of Ukraine. [The concept of distance education development in Ukraine in 2020]. Resolution of the Ministry of Education and Science of Ukraine. 2020;(1):3-7. Ukrainian.

5. Polyvkan MI. [Role of independent work in development of professional competence of medical specialists]. Aktualni problemy suchasnoi medytsyny. Visnyk ukrainskoi medychnoi stoma- 
tolohichnoi akademii. 2020;20(70):236-239. Ukrainian. https://doi.org/10.31718/2077-1096.20.2.236

6. Papa V, Vaccarezza M. Teaching Anatomy in the XXI Century: New Aspects and Pitfalls. The Scientific World Journal. 2013;5:10348. https://doi.org/10.1155/2013/310348.

Іванців О.Р. Особливості дистанційної форми викладання дисципліни “Клінічна анатомія та оперативна хірургія" у студентів Івано-Франківського національного медичного університету.

РЕФЕРАТ. Актуальність. Уся медична спільнота України із середини березня 2020 року зіткнулася із новою проблемою - відсутністю досвіду та технічного забезпечення проведення занять в дистанційному режимі. Мета: проаналізувати особливості дистанційної форми викладання дисципліни "Клінічна анатомія та оперативна хірургія" у студентів II курсу медичного факультету ІФНМУ. Результати. Перш за все, нами виділено переваги дистанційного навчання. Так, перебуваючи вдома, студенти можуть оволодіти знаннями за умов постійного опрацювання навчального матеріалу, тому їхня теоретична база буде досить грунтовною; дистанційне навчання забезпечує можливість вивчення матеріалу у будь-якому місці, де є можливість підключення до інтернету, у спокійній домашній обстановці, надає можливість оволодівати сучасними інформаційно-комунікаційними технологіями. Проте є і недоліки даної форми навчання: неможливість сформувати повне уявлення та відтворити практичні навички 3 дисципліни самостійно, через відсутність в домашніх умовах необхідного інструментарію, фантомів, муляжів тощо, таким чином складним є отримання якісних знань, низька спроможність електронної мережі. Висновки. В процесі проведеного навчання студентів-медиків нами окреслено наступні особливості дистанційної форми проведення занять: віддаленість, гнучкість, масовість, апрактичність, економічність, паралельність, модульність.

Ключові слова: дистанційне навчання, студенти-медики, освіта, практичні навички, інтернет.

Иванцив О.Р. Особенности дистанционнои формы обучения дисциплины "Клиническая анатомия и оперативная хирургия" у студентов Ивано-Франковского национального медицинского университета.

РЕФЕРАТ. Актуальность. Все медицинское сообщество Украины с середины марта 2020 столкнулась с новой проблемой - отсутствием опыта и технического обеспечения проведения занятий в дистанционном режиме. Цель: проанализировать особенности дистанционной формы преподавания дисциплины "Клиническая анатомия и оперативная хирургия" у студентов II курса медицинского факультета ИФНМУ. Результаты. Прежде всего, нами выделено преимущества дистанционного обучения. Так, находясь дома, студенты могут овладеть знаниями в условиях постоянного изучения учебного материала, поэтому их теоретическая база будет достаточно основательной; дистанционное обучение обеспечивает возможность изучения материала в любом месте, где есть возможность подключения к интернету, в спокойной домашней обстановке, дает возможность овладевать современными информационнокоммуникационными технологиями. Однако есть и недостатки данной формы обучения: невозможность сформировать полное представление и воссоздать практические навыки по дисциплине самостоятельно, из-за отсутствия в домашних условиях необходимого инструментария, фантомов, муляжей и т.п., таким образом сложным является получение качественных знаний, низкая способность электрической сети. Выводы. В процессе проведенного обучения студентов-медиков нами обозначены следующие особенности дистанционной формы проведения занятий: удаленность, гибкость, массовость, апрактичнисть, экономичность, параллельность, модульность.

Ключевые слова: дистанционное обучение, студенты-медики, образование, практические навыки, интернет. 